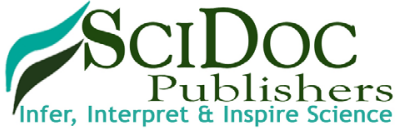

International Journal of Forensic Science \& Pathology (IJFP) ISSN 2332-287X

\title{
First Forensic Record of Blowfly, Calliphora vicina, Larvae on an Indoor Human Corpse in Winter, South of Iran
}

Keshavarzi $\mathrm{D}^{1}$, Moemenbellah-Fard $\mathrm{MD}^{1^{*}}$, Zarenezhad $\mathrm{M}^{2}$, Gholamzadeh $\mathrm{S}^{2}$

Case Study

${ }^{1}$ Research Centre for Health Sciences, School of Health, Shiraz University of Medical Sciences, Shiraz, Iran.

${ }^{2}$ Legal Medicine Research Centre, Legal Medicine Organization, Tehran, Iran.

\section{Abstract}

A new report of necrophagous blowfly, Calliphora vicina (Diptera: Calliphoridae), larvae from a human corpse found in the bathroom of a house during winter in Shiraz, Fars province, south of Iran, is presented. An autopsy revealed that the cadaver was an 83-year-old solitary-living Iranian female having a stroke during bath. The minimum time elapsed since death was estimated to have been less than 5 days prior to the discovery of the bloated cadaver at defined ambient temperatures. As such, this synanthropic species was associated with the early wave of colonizing cadaver-feeding insects that were found on a corpse after death. This is the first corroborated evidence of a forensic entomology case involving this bluebottle blowfly species of insect in south of Iran and this species can be helpful in the future to support the estimation on the time elapsed since death in this region.

Keywords: Forensic Entomology; Calliphora Vicina; Fly Larvae; Winter; Indoor; Iran.

\section{Introduction}

Use of insects in forensic entomology investigations can often be found to have many applications. The study of Diptera as early colonizing insects is important in medicolegal case examination. This can be useful in estimating the elapsed time since death or postmortem interval (PMI) and postmortem transfer [1]. One way of reckoning PMI using insect evidence is to use the growth and developmental rates of the first generation of visiting insects such as blowflies, houseflies or fleshflies. Insects have a particular ecological sequence to attack the cadavers, as Diptera are usually found in the initial stages of body decomposition $[2,3]$, while Coleoptera such as dermestid, nitidulid and staphylinid beetles are late colonizers [4-7]. Hence, the study of insect fauna isolated from human cadavers and their life history patterns is important in each place because there are multiple differences between insect fauna associated with human corpses in each region [8]. Flies are faster than other insects like beetles infesting human bodies. The Calliphora genus, also known as bluebottles, was recently reported on a cadaver as soon as 2-3 h after death [9]. The urban bluebottle blowfly species, Calliphora vicina Robineau-Desvoidy 1830, have been reported on human corpses both in outdoor and indoor settings [10]. However, the utility of this insect in forensic cases has been neglected in Iran and this study can be useful in the future medicolegal investigations.

\section{Case Study}

An 83-year old woman was found dead in the bathroom of a house in Shiraz $\left(29^{\prime} 62^{\circ} \mathrm{N}, 52^{\prime} 53^{\circ} \mathrm{E}\right)$, the capital city of Fars province, south of Iran. She was taken to Shiraz Institute of Legal Medicine on Tuesday $24^{\text {th }}$ February 2015. The victim had apparently lived alone and died while bathing. The cause of death was a stroke following autopsy. Her corpse was unclothed and in the bloat stage of body decomposition (Figure 1). Time of death was estimated to have been less than 5 days prior to the discovery of the body based on forensic exam report. The ambient minimal and maximal temperatures from the time of the woman's last appearance in public to the discovery of her cadaver were -4 and $16^{\circ} \mathrm{C}$, respectively. The temperature chart over the PMI period obtained from the nearest weather station to the location where the body was found is shown in Figure 2.

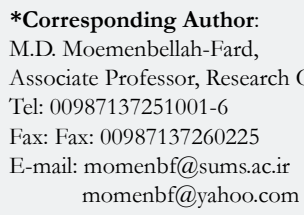

Citation: Keshavarzi D, Moemenbellah-Fard MD, Zarenezhad M, Gholamzadeh S (2016) First Forensic Record of Blowfly, Calliphora vicina, Larvae on an Indoor Human Corpse in Winter, South of Iran. Int J Forensic Sci Patbol. 4(1), 218-220. doi: http://dx.doi.org/10.19070/2332-287X-1600052 
Figure 1. A female human corpse at the bloat stage of decomposition found in a bath inside a house in Shiraz, Fars province, south of Iran.

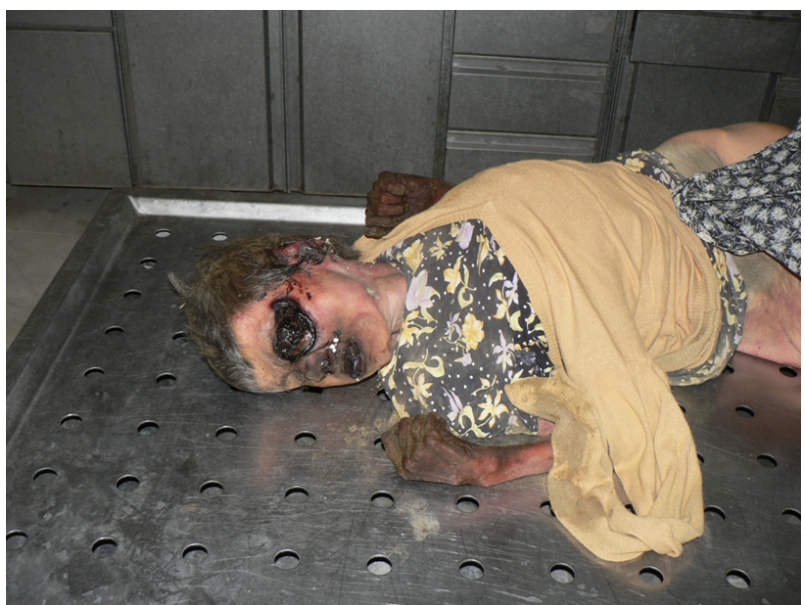

Figure 2. Changes in maximum and minimum ambient temperature between the time when the woman was last seen to when it was found in a bathroom in February 2015, in the capital city Shiraz, Fars province, south of Iran.

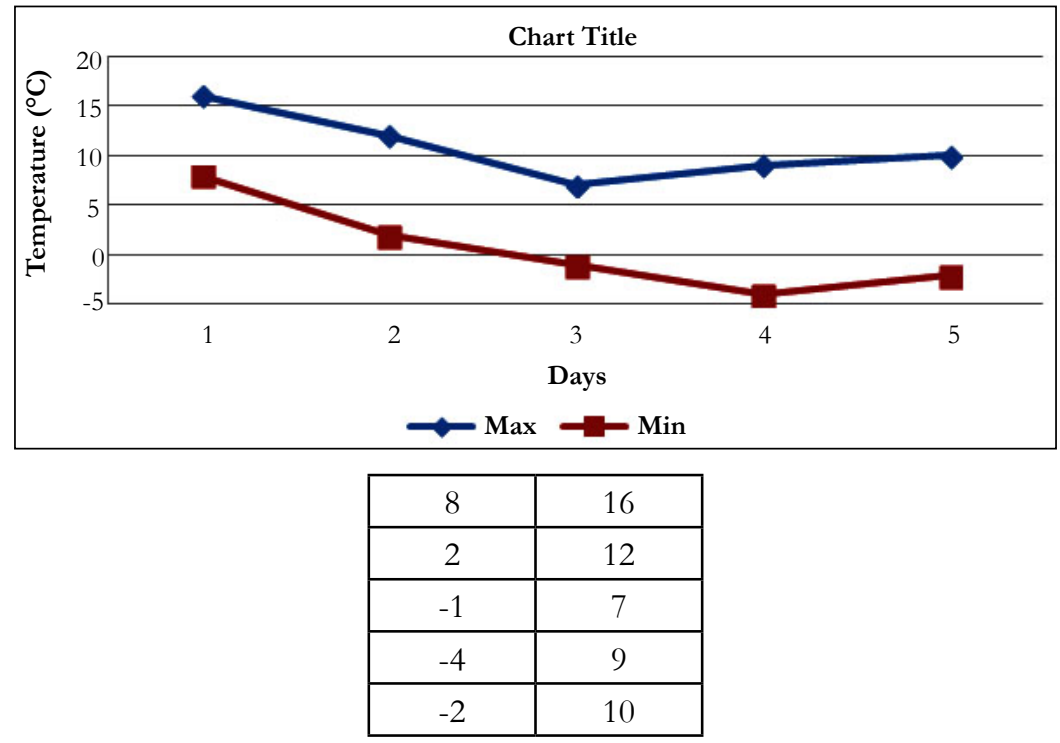

In this case, a total of 187 blowfly larvae (maggots) were collected from the corpse (mainly on the head from ears and eyes) during autopsy procedure by the third author at 9:30 am. The collected larvae from the corpse were transferred to the Maggotarium of the Medical Entomology Laboratory, School of Health, Shiraz University of Medical Sciences, for breeding and final identification. The live larvae were reared in petri dishes with beef meat. The temperature of the rearing room was set at $21 \pm 1^{\circ} \mathrm{C}$ and measured daily. The adults that emerged from pupae were killed and pinned for identification by using valid taxonomic keys [11-13].

The adult in the genus of Calliphora is recognized by its relatively robust size (12-14mm long), dull-grey or black thorax, metallic dark blue abdomen, transparent wings with bare stem vein but hairy squama on the dorsal side and the presence of presutural intra-alar bristles.

Calliphora vicina species can be distinguished from other species by a yellow basicosta, short and dark hairs on posteroventral side of the head (immediately behind the cheek) and a genal dilation with reddish ground color on anterior half.

\section{Discussion}

Since insect larvae live on decomposing human tissues both as a food source and as a habitat to grow to their next instar stages, they could be manipulated to estimate the postmortem interval in line with the data on species of insect, their growth rates and fluctuating environmental temperatures [2]. Forensic entomology has thus increasingly gained significance in medicolegal investigations. It is, however, a neglected field among medicolegal sciences in Iran. This is the first documented report of dipteran insect evidence from a human corpse in a closed environment in the city of Shiraz, south of Iran. Therefore, research in this field is essential and the main aim of this study was to introduce the synanthropic Calliphora vicina on a human corpse as an important indoor species during winter season in this area. The outdoor post-mortem associated activity of this species has previously been reported [14].

The species of $C$. vicina is more frequently present in the cooler 
months of the year $[14,15]$, because low temperatures $\left(<30^{\circ} \mathrm{C}\right)$ are necessary for life in this species [17]. This species has been reported to have a minimal developmental threshold of $1{ }^{\circ} \mathrm{C}$ [18]. A number of authors have reported this species during cold season on human corpses $[9,16]$. Our study revealed that $C$. vicina can be important in medicolegal investigations in this city at low temperatures $\left(-4\right.$ to $\left.2^{\circ} \mathrm{C}\right)$ during winter.

The bluebottle blowfly, C. vicina, is most likely one of the first colonizers on decomposing tissues of human remains. It usually visits the corpse soon (within minutes to hours) after death to oviposit (lay eggs). The newly-hatched larvae feed their way through the protein rich human tissues, infiltrate and disperse deeply to other nutritious organs, where they develop and survive successfully. As a result of the foraging behavior of the larvae, an infinitesimal increment of temperature could affect their survival. Low ambient temperature, however, postpones their development into adults.

In the present paper, the forensic entomological data indicated that the old lady had most likely died on or around February 20. In addition, the indoor ambient temperature was sufficiently high for blowflies to lay their eggs. It is noteworthy that the insect larvae were live at the autopsy. They moved to other organs. The data acquired on these insects could vindicate the police information. The present study validated the significance of collecting blowflies on human corpses during cold months to estimate the elapsed time since death.

Studies on the presence of this species on animal carcasses in this area during the year and on the life cycle of this species in the future could be helpful in legal cases to estimate the postmortem interval (PMI). One of the limitations in the present study was the inaccessibility of entomologist at the crime scene due to the strict regional regulations. The second limitation was the lack of knowledge of the error rate of PMI estimate. The third restriction was that the temperature fluctuation as a result of maggots activity on the corpse was not considered in PMI estimate. Examination of the life cycle of each insect species in each region is indispensible, since populations of the same species can differ physiologically depending on their geographical origin. As a result, the growth rates may be different in distinct regions [18]. Therefore, further studies on this species are needed to elaborate the application of this species to forensic investigations.

\section{Acknowledgements}

This article has been extracted from parts of Mr. Davood Keshavarzi's MSc thesis supported by the Research Council of Shiraz University of Medical Sciences (Thesis Code: 7295).

\section{References}

[1]. Catts EP, Goff ML (1992) Forensic entomology in criminal investigations. Ann Rev Entomol 37: 253-272.

[2]. Gennard D (2007) Forensic Entomology: An Introduction. John Wiley \& Sons, England.

[3]. Hitosugi M, Kirinoki M, Ishii K, Morita S, Furukawa S, et al. (2014) The importance of collecting live fly larvae from a severely decomposed human cadaver in winter-Case report. Rom J Leg Med 22: 253-256.

[4]. Keshavarzi D, Moemenbellah-Fard MD, Fereidooni M, Montazeri M (2015) First report of Dermestes frischii Kugelann (Coleoptera: Dermestidae) on a human corpse, South of Iran. Intl J Forensic Sci Pathol 3(4): 113-115.

[5]. Keshavarzi D, Moemenbellah-Fard MD, Fereidooni M, Zarenezhad M, Fakoorziba MR (2015) New record of sap beetle, Nitidula flavomaculata Rossi (Coleoptera: Nitidulidae) on an outdoor mummified human corpse, South of Iran. J Entomol Zool Stud 3(3): 396-399.

[6]. Magni PA, Voss SC, Testi R, Borrini M, Dadour IR (2015) A biological and procedural review of forensically significant Dermestes species (Coleoptera: Dermestidae). J Med Entomol 755-769.

[7]. Keshavarzi D, Fereidooni M, Moemenbellah-Fard MD, Nasiri Z, Soltani Z, et al. (2015) Preliminary data on life cycle of Creophilus maxillosus Linnaeus (Coleoptera: Staphylinidae) and new report of this species on a human corpse, south of Iran. Int J Forensic Sci Pathol 3(7): 144-147.

[8]. Campobasso CP, DiVella G, Introna F (2001) Factors affecting decomposition and Diptera colonization. Forensic Sci Int 120(1-2): 18-27.

[9]. Pohjoismäki JL, Karhunen PJ, Goebeler S, Saukko P, Sääksjärvi IE (2010) Indoors forensic entomology: colonization of human remains in closed environments by specific species of sarcosaprophagous flies. Forensic Sci Int 199(1-3): 38-42.

[10]. Reibe S, Madea B (2010) How promptly do blowflies colonise fresh carcasses? A study comparing indoor with outdoor locations. Forensic Sci Int 195(1-3): 52-57.

[11]. Zumpt F (1965) Myiasis in man and animals in the Old World. Butterworths, London.

[12]. Whitworth T (2010) Keys to the genera and species of blow flies (Diptera: Calliphoridae) of the West Indies and description of a new species of Lucilia Robineau-Desvoidy. Zootaxa 2663: 1-35.

[13]. Ubero-Pascal N, López -Esclapez R, García MD, Arnaldos MI (2012) Morphology of preimaginal stages of Calliphora vicina Robineau-Desvoidy, 1830 (Diptera, Calliphoridae): a comparative study. Forensic Sci Int 219(1-3): 228-243.

[14]. Moemenbellah-Fard MD, Keshavarzi D, Fereidooni M, Soltani A, Gholamzadeh S, et al. (2015) First case report of Calliphora vicina (Diptera: Calliphoridae) on an outdoor human corpse with an estimation of postmortem interval from Iran. J Entomol Zool Stud 3(3): 400-402.

[15]. Marshall SA, Whitworth T, Roscoe L (2011) Blow flies (Diptera: Calliphoridae) of eastern Canada with a key to Calliphoridae subfamilies and genera of eastern North America, and a key to the eastern Canadian species of Calliphorinae, Luciliinae and Chrysomyiinae. Can J Arthropod Identification 11: 1-93.

[16]. Bonacci T, Vercillo V, Brandmayr P, Fonti A, Tersaruolo C, et al. (2009) A case of Calliphora vicina Robineau-Desvoidy, 1830 (Diptera, Calliphoridae) breeding in a human corpse in Calabria (Southern Italy). Leg Med 11(1): 30-32.

[17]. Bharti M (2009) Studies on the life cycles of forensically important flies, Calliphora vicina and Musca domestica nebulo at different temperatures. J Entomol Res 33(3): 273-275.

[18]. Donovan SE, Hall MJ, Turner BD, Moncrieff CB (2006) Larval growth rates of the blow fly, Calliphora vicina, over a range of temperatures. Med Vet Entomol 20(1): 106-114. 